\title{
scripted
}

Volume 17, Issue 1, January 2020

\section{No man is an island: A critical analysis of the UK's implementation of the Marrakesh Treaty}

\author{
Jade Kouletakis*
}

(ㄷ) (1) $(9)$

(C) 2020 Jade Kouletakis

Licensed under a Creative Commons Attribution-NonCommercialNoDerivatives 4.0 International (CC BY-NC-ND 4.0) license

DOI: 10.2966/scrip.170120.54

\begin{abstract}
The Marrakesh Treaty to Facilitate Access to Published Works for Persons Who Are Blind, Visually Impaired, or Otherwise Print Disabled was signed on behalf of the European Union on 30 April 2014. On 13 September 2017, the European Union created a Directive (2017/1564) implementing its obligations under the Marrakesh Treaty. This Directive and corresponding Regulations came into force on 12 October 2018, which was the deadline provided to member states in implementing the Directive. On the $11^{\text {th }}$ of September 2018, the United Kingdom made the Copyright and Related Rights (Marrakesh Treaty etc.) (Amendment) Regulations 2018. The UK's Marrakesh Regulations came into force the day before the EU deadline, and the lack of in-depth critical debate around this piece of legislation as well as the EU having initiated legal proceedings against the UK underscores the necessity of this paper. This paper seeks to assess the UK's Marrakesh Regulations in light of both the EU legislation as well as non-EU international obligations to which the UK will remain bound beyond Brexit. This paper will ask: Can it be said that the UK in implementing the
\end{abstract}


Marrakesh Treaty is fulfilling its obligations owed both to the EU as well as its own citizens?

\section{Keywords}

Disability, copyright, Marrakesh Treaty

* Lecturer in Law, Dundee Business School, Abertay University, Scotland, United Kingdom j.kouletakis@abertay.ac.uk 


\section{Introduction}

The Marrakesh Treaty to Facilitate Access to Published Works for Persons Who Are Blind, Visually Impaired, or Otherwise Print Disabled 2013 (henceforth the "Marrakesh Treaty") was signed on behalf of the European Union on 30 April 2014. On 13 September 2017, the EU created a Directive (henceforth the "Marrakesh Directive") implementing its obligations under the Marrakesh Treaty, ${ }^{1}$ as well as corresponding Regulations. ${ }^{2}$ The Marrakesh Directive and Regulations came into force on 12 October 2018, which was the deadline provided to member states in implementing the Marrakesh Directive. Prior to this, the UK government launched a public consultation seeking views on how the UK should approach the implementation of the Marrakesh Directive. ${ }^{3}$ This was captured, ${ }^{4}$ and in September of 2018 the Intellectual Property Office published the "Government Response to Marrakesh Consultation". ${ }^{5}$ The publication of these findings, coupled with the looming October deadline for

1 Directive (EU) 2017/1564 of the European Parliament and of the Council of 13 September 2017 on certain permitted uses of certain works and other subject matter protected by copyright and related rights for the benefit of persons who are blind, visually impaired or otherwise print-disabled and amending Directive 2001/29/EC on the harmonisation of certain aspects of copyright and related rights in the information society.

2 Regulation (EU) 2017/1563 of the European Parliament and of the Council of 13 September 2017 on the cross-border exchange between the Union and third countries of accessible format copies of certain works and other subject matter protected by copyright and related rights for the benefit of persons who are blind, visually impaired or otherwise print-disabled.

3 Intellectual Property Office, "Call for views: Modernising the European copyright framework" (2016), available at: https://www.gov.uk/government/news/call-for-viewsmodernising-the-european-copyright-framework (accessed 17 June 2018).

4 Intellectual Property Office, "Consultation on UK's implementation of the Marrakesh Treaty." (2018), available at: https://www.gov.uk/government/consultations/uk-implementation-ofthe-marrakesh-treaty (accessed 17 June 2018).

5 Intellectual Property Office, "Government Response to Marrakesh Consultation" (2018), available at:

https://assets.publishing.service.gov.uk/government/uploads/system/uploads/attachment d ata/file/738669/Marrakesh-Government-Response.pdf (accessed 14 October 2018). 
implementing the Marrakesh Directive, meant that within hours of said publication the Copyright and Related Rights (Marrakesh Treaty etc.) (Amendment) Regulations 2018 (henceforth the "UK Marrakesh Regulations") were made. These regulations came into force the day before the EU deadline. The lack of in-depth critical debate around this piece of legislation as well as the EU's announcement of having instigated legal proceedings against the UK on the basis of these Regulations, ${ }^{6}$ underscores the necessity of this paper. This paper seeks to assess the UK's Marrakesh Regulations in light of both the EU's Marrakesh Directive and Regulations as well as other non-EU legislation to which the UK will remain bound post-Brexit. This paper will ask: Can it be said that the UK in implementing the Marrakesh Treaty is fulfilling its obligations owed both to the EU as well as its own citizens? In answering this, it will be evidenced that the UK is both acting in violation of article 10 of the Marrakesh Directive as well as failing to give adequate effect to the spirit and purport of the Marrakesh Treaty, both of which may have significantly negative impacts upon the realisation of human rights by its own nationals, as well as legal implications for the UK as a whole.

\section{Brexit and the continuing relevance of the Marrakesh Treaty}

The examination undertaken by this paper is particularly relevant in light of the ongoing Brexit matters that have been dominating socio-political life in the UK over the past few years. As is well-known, the UK has elected to exit the EU, with

6 Mathilde Pavis, "Marrakesh Treaty is no paper tiger: EU Commission sues 17 countries for non-compliance" (2018). Available at: http://ipkitten.blogspot.com/2018/11/marrakesh-treatyis-no-paper-tiger-eu.html (accessed 28 November 2018). 
its membership ceasing at a future date which remains the subject of much political debate. A necessary result of Brexit will be that the UK's external relationships are - or will be - founded upon a host of bi and multilateral agreements which will govern, among other areas, intellectual property (IP). IP provides a unique avenue from which to view the socio-political concerns arising from Brexit, as IP amalgamates both economic aspects (e.g. trade in IP-related goods) as well as public interest and human right aspects (e.g. access to copyright works for the visually impaired, limitations on monopoly rights in patents and so on). It is argued that this overlap between trade/economics and human rights is most perspicuous in the Marrakesh Treaty. On the one hand, the Marrakesh Treaty aims to regulate the cross-national import and export of reading materials. On the other hand, it seeks to increase access to said reading materials by visually impaired individuals who make up one of the most marginalised sectors of society (and thereby invoking/aiding said communities to realise rights such as access to education, culture, political participation and so on). ${ }^{7}$

It is important to stress that the Marrakesh Treaty is a legal instrument wholly unrelated to the EU, although member states of the EU are bound by the Marrakesh Treaty by virtue of the EU's signatory status. If Brexit materialises the UK will no longer be bound by the Marrakesh Treaty. However, EU laws

Laurence R. Helfer et al., The World Blind Union Guide to the Marrakesh Treaty: Facilitating Access to Books for Print-Disabled Individuals. (London: OUP, 2017); Charles Oppenheim, "The Marrakesh Copyright Treaty for those with visual disabilities and its implications in the European Union and in the United Kingdom" (2017) 27(1) Alexandria: The Journal of National and International Library and Information Issues 4-9, pp. 4-6; Jingyi Li and Nilonfer Selvadurai, "Reconciling the enforcement of copyright with the upholding of human rights: a consideration of the Marrakesh Treaty to Facilitate Access to Published Works for the Blind, Visually Impaired and Print Disabled" (2014), 36(10) European Intellectual Property Review 653664. 
(including the Marrakesh Directive) will remain binding on the UK until the agreed date on which EU membership ceases has been reached. Directives must be implemented by member states in their own legal system by a specified date and are binding from said date onward. If an EU member state fails to communicate measures that fully transpose the provisions of Directives, or does not rectify a suspected violation of EU law, the Commission may launch a formal infringement procedure against said member state. This may include taking the matter to the Court of Justice (whose decisions must be complied with by the infringing member state), and potentially facing financial penalties. ${ }^{8}$ That the EU has already instigated legal proceedings against the UK indicates the seriousness with which it takes the Marrakesh Directive, as well as its willingness to hold the UK to account despite Brexit being an ongoing concern. ${ }^{9}$

Furthermore, the UK has expressed its intention to become an independent signatory to the Marrakesh Treaty post-Brexit. ${ }^{10}$ As explained below, the means by which the UK may implement the Marrakesh Treaty independently will be wider post-Brexit; this makes the call for academic discourse on how best to implement the Marrakesh Treaty prior to its membership ceasing even more important, as there will be a lacuna period between exiting the EU and becoming a signatory to the Marrakesh Treaty.

8 European Commission, "Infringement Procedure" (2019), available at: https://ec.europa.eu/info/law/law-making-process/applying-eu-law/infringementprocedure en (accessed 14 April 2019).

9 The author contacted the Intellectual Property Office on 16 April 2019 via email to enquire about these proceedings, and received the following response: "In late 2018 the European Commission did start infraction proceedings against the UK, but this non-compliance was not related to our implementation of the Directive but rather to the fact that we were yet to notify the Commission that we had implemented the Marrakesh Directive on time. The delay in notifying the Commission was due to an oversight and we can confirm that notification has now taken place."

10 Intellectual Property Office, "Call for views: Modernising the European copyright framework", supra n. 3. 
Lastly, post-Brexit the UK will no longer be bound by EU law but it will remain bound to its non-EU commitments (which are discussed later in the paper) which ought to influence the way in which the UK may exercise its discretion as an independent signatory. Therefore, both the degree and means by which the UK implements the spirit and purport of the Marrakesh Treaty will remain a relevant concern regardless of Brexit.

\section{The Marrakesh Treaty: Key provisions}

In order to fully appreciate the importance of the Marrakesh Treaty, one must understand the implications of it for the visually impaired. First the application of the Marrakesh Treaty must be identified by understanding who the beneficiaries are in terms of the Treaty. According to article 3:

A beneficiary person is a person who:

(a) is blind;

(b) has a visual impairment or a perceptual or reading disability which cannot be improved to give visual function substantially equivalent to that of a person who has no such impairment or disability and so is unable to read printed works to substantially the same degree as a person without an impairment or disability; or

(c) is otherwise unable, through physical disability, to hold or manipulate a book or to focus or move the eyes to the extent that would be normally acceptable for reading;

regardless of any other disabilities.

The limitations and exceptions promoted in the Marrakesh Treaty are to be confined to the benefit of the above-mentioned people. Interestingly, the initial version of the Marrakesh Treaty did in fact include exemptions for those 
suffering from other sensory disabilities other than visual impairments. ${ }^{11}$ However, this was excluded from the final draft of the Marrakesh Treaty after the United States insisted they be excluded from the scope of the Treaty. ${ }^{12}$ This means that people who are inflicted with other sensory disabilities, such as hearing loss, are excluded from the benefits enjoyed within the Marrakesh Treaty. However, it should be remembered that the Marrakesh Treaty provides for minimum standards: signatories are free to broaden the definition of beneficiary persons according to their own preferences and may choose to alter their copyright laws in order to include those with other sensory disabilities, a has been the case in some jurisdictions. ${ }^{13}$

The heart of the Marrakesh Treaty can be found in article 4(1)(a). This puts a general requirement on all contracting parties to amend their current copyright laws in so far as they fail to provide limitations and exceptions pertaining to the visually impaired converting traditional format literary works into accessible formats. In this way the Marrakesh Treaty addresses one of traditional manners in which legislation has failed to achieve equal access with regards to such works between able bodied individuals and the visually impaired community. It is important to note that the limitations and exceptions in the Marrakesh Treaty 'do not extend to substantive modifications that would amount to adaptations', an exclusive right given to the copyright owner of a literary work according to

11 E.g. WIPO, "Draft Consensus Instrument: Proposal by the Delegation of the United States of America" (2010), available at: http://www.wipo.int/edocs/mdocs/copyright/en/sccr 20/sccr 20 10.pdf (accessed 04 March 2018).

12 James Love, "Final text before Marrakesh, WIPO treaty for the blind" (2013), available at: http://keionline.org/node/1707 (accessed 26 June 2017).

13 Jingyi Li, "Legislative comment: Copyright exemptions to facilitate access to published works for the print disabled - the gap between national laws and the standards required by the Marrakesh Treaty" (2014) 45 International Review of Intellectual Property and Competition Law 740-767, pp. 741-744. 
article 12 of the Berne Convention for the Protection of Literary and Artistic Works 1886 and which is omitted from article 4(1)(a) of the Marrakesh Treaty. Therefore, all that is permitted is the transformation of the traditional formatted work into an accessible format, not the adaptation or alteration of the content of the original work itself. The integrity of the original work as per article 2(b) of the Berne Convention is to be respected at all times, and therefore issues of potential infringement on the moral integrity of the author ought not to arise.

One of the most novel aspects of the Marrakesh Treaty is the provision pertaining to the cross-border exchange of accessible format copies of copyright protected works, namely article 5(1). What article 5(1) means is that the territorial nature of copyright law is relaxed, allowing for a copyright exception pertaining to the import and export of reading material in accessible formats for the visually impaired. In practical terms, it is that there will be a newly created copyright exception allowing e.g. a visually impaired person in Country $X$ to request a book in an accessible format via a local organisation, and for an organisation in Country $Y$ - where the book happens to be available in the said format - to export the said book to the requesting organisation in Country $X$ where the visually impaired person may have access to it. ${ }^{14}$ This is life changing for the visually impaired population. It means that there would be a reciprocal relationship whereby countries with a common-language would be able to share resources available (e.g. the free exchange of accessible format copies of books in English could be shared between developed countries like the UK and US, as well as developing countries like South Africa and Jamaica). This provision therefore

14 Jade Kouletakis, "A critical examination of copyright limitations and exceptions for the visually impaired pertaining to literary works in South Africa in the local and global context" (2014) 2 South African Intellectual Property Law Journal 42-65. 
allows for the avoidance of duplicate expenditure in having to make accessible format copies of the same work in the same language, which in turn makes it easier for the visually impaired community to have accessible format works available. ${ }^{15}$ It is important to stress that this logic applies equally to developed and developing countries that share a common language and the desire to save resources, ${ }^{16}$ e.g. English-speaking South Africans would benefit from the importation of books from the UK as much as the UK would benefit from the importation of books from the United States. On the other hand, allowing for parallel importation may have the effect of limiting the copyright owner's exclusive right of distribution in favour of visually impaired individuals over sighted individuals, although it has been argued that this potential drawback is outweighed by its overall benefits and limited scope within the Marrakesh Treaty. ${ }^{17}$

In addition to the aforementioned requirements, the Marrakesh Treaty introduces two main flexibilities for Contracting Parties, namely the potential to introduce a so-called "commercial availability" requirement, as well as the potential to introduce a compensation scheme. The former can be found in article 4(4) which permits - but does not require - Contracting Parties to confine the limitations or exceptions given to the visually impaired population to circumstances where an accessible format work "cannot be obtained

15 Ibid.

16 Rami Olwan, "The ratification and implementation of the Marrakesh Treaty for visually impaired persons in the Arab Gulf States" (2017) 20 The Journal of World Intellectual Property 178-205.

17 Tobias Schonwetter et al., "Marrakesh Treaty Implementation Guide for South Africa” (2015), available at http://ip-unit.org/2015/1251/ (accessed 16 August 2018); Kouletakis, supra n. 14; Paul Harpur and Nicolas Suzor, "Copyright protections and disability rights: turning the page to a new international paradigm" (2013) 36 (3) University of New South Wales Law Journal 745778. 
commercially under reasonable terms for the beneficiary persons in that market". One of the by-products of a country availing itself of the commercial availability requirement is that article 5(1) will not apply to accessible format copies which may be obtained commercially and under reasonable terms. Article 5(1) states that Contracting Parties must provide that if an accessible format copy is made in terms of the Treaty, the accessible format copy may be distributed or made available by an authorised entity to a beneficiary person or an authorized entity in another Contracting Party. No definition for "commercial availability" or "reasonable terms" is provided for in the Treaty. Under article 4(5), the Treaty permits Contracting Parties to decide as a matter of national law whether the exercise of the limitations and exceptions under the Treaty will be subject to remuneration. It therefore permits for the creation, distribution, or making available of accessible format copies upon the payment of a royalty or other license fee to the copyright holder. In doing so, this cost may fall on either the beneficiary person or the authorised entity, depending on national legislation. ${ }^{18}$

It is therefore evident that, while the Marrakesh Treaty does require uniformity among its signatories, there is a wide scope for discretion when it comes to implementing the spirit and purport of the Marrakesh Treaty. It is in dealing with these flexibilities that this paper examines the UK's position in implementing the Marrakesh Treaty.

\section{The implementation of the Marrakesh Treaty: The EU's approach}

As explained above, the UK is and may remain (depending upon whether Brexit

18 Helfer et al., supra n. 7; Schonwetter et al., supra n. 17; Kouletakis, supra n. 14. 
materialises) bound by EU laws. It is therefore important to understand the EU'S position with regards to implementing the Marrakesh Treaty, for this is necessary in order to assess whether the UK's Marrakesh Regulations fulfil the EU obligations (as dealt with later in the paper).

In 2012 the European Council authorised the European Commission to participate, on behalf of the EU, in negotiations within the framework of the World Intellectual Property Organisation (WIPO) on the future Marrakesh Treaty. When the treaty was adopted on 27 June 2013, the Commission took the view that the EU itself (without the participation of the member states) could conclude the Marrakesh Treaty and subsequently put forward a proposal for a decision on the conclusion of the treaty. This decision was not adopted by the Council. The Commission then asked the Court of Justice to give its Opinion on whether the Marrakesh Treaty may be concluded by the EU acting on its own or whether the participation of the member states is necessary for that purpose. The Court in Opinion 3/15 recognised that copyright and related rights with which the Marrakesh Treaty is concerned and in particular the exceptions and limitations to those rights have been harmonised at EU level by Directive 2001/29. ${ }^{19}$ It therefore ruled that the body of obligations laid down by the Marrakesh Treaty falls within an area that is already covered to a large extent by common EU rules and the conclusion of that treaty may thus affect those rules or alter their scope, ${ }^{20}$ and therefore the conclusion of the Marrakesh Treaty falls within the exclusive jurisdiction of the EU.

On 13 September 2017, the Council adopted implementing legislation to introduce into EU law the new mandatory exception to copyright rules, in line

19 Court of Justice (Grand Chamber) Opinion 3/15 of 14 February 2017, para. 34.

$20 \quad$ Ibid., para. 129. 
with the Marrakesh Treaty (Marrakesh Directive 2017/1564). ${ }^{21}$ According to article 7 of the Marrakesh Directive, the definition of beneficiary persons is broad enough to cover a host of disabilities effecting one's ability to read, from dyslexia to physical impairments and more.

With regards to defining an "accessible format", the Marrakesh Directive is quite broad:

This Directive [...] aims to improve the availability of books, including ebooks, journals, newspapers, magazines and other kinds of writing, notation, including sheet music, and other printed material, including in audio form, whether digital or analogue, online or offline, in formats that make those works and other subject matter accessible to those persons to substantially the same degree as to persons without such impairment or disability. Accessible formats include, for example, Braille, large print, adapted e-books, audio books and radio broadcasts. ${ }^{22}$

The corresponding Regulations aims to implement the obligations under the Marrakesh Treaty with respect to the export and import arrangements for accessible format copies for non-commercial purposes for the benefit of beneficiary persons between the EU and third countries that are parties to the Marrakesh Treaty, and to lay down the conditions for such export and import in a uniform manner. ${ }^{23}$

According to article 3 of the Regulations:

An authorised entity established in a Member State may distribute, communicate or make available to beneficiary persons or to an authorised

\footnotetext{
21 Directive (EU)2017/1564, supra n. 1.

22 Ibid, art. 7.

23 Regulation (EU) 2017/1563, supra n. 2, para. 5.
} 
entity established in a third country that is a party to the Marrakesh Treaty an accessible format copy of a work or other subject matter made in accordance with the national legislation adopted pursuant to Directive (EU) $2017 / 1564$.

Correspondingly, according to article 4:

A beneficiary person or an authorised entity established in a Member State may import or otherwise obtain or access and thereafter use, in accordance with the national legislation adopted pursuant to Directive (EU) 2017/1564, an accessible format copy of a work or other subject matter that has been distributed, communicated or made available to beneficiary persons or to authorised entities, by an authorised entity in a third country that is a party to the Marrakesh Treaty.

It is therefore clear that the EU provides for direct access to accessible format copies (i.e., by both beneficiary persons as well as authorised entities).

According to article 3(6), member states are permitted to introduce compensation schemes, provided that such compensation schemes only apply to authorised entities, should not require payments by authorised entities established in other member states or third countries to the Marrakesh Treaty, and do not require payments from beneficiary persons. According to article 10, in 2023 the Commission will undertake a review that will "include an assessment of the impact of compensation schemes, provided for by member states pursuant to article 3(6), on the availability of accessible format copies for beneficiary persons and on their cross-border exchange". While it is not ideal for there to be the implementation of compensation schemes (as addressed below), the very limited nature and review in 2023 means that the Marrakesh Directive has, in so far as possible, struck a balance between providing for autonomous 
implementation by member states while at the same time ensuring a minimum standard that does meet with the objectives of the Marrakesh Treaty.

\section{The implementation of the Marrakesh Treaty: The UK's approach}

In light of the recent coming into force of the UK's Marrakesh Regulations, it has yet to be the subject of any in-depth academic discourse, although it has become the subject of a court action by the European Commission. What follows will be an examination of what, it is suggested, may be considered the two main areas of contention regarding the UK's Marrakesh Regulations, namely: The compensation scheme, and the commercial availability requirement. In considering these issues, it will be argued that - in its current form - the UK's Marrakesh Regulations violates the Marrakesh Directive and potentially violates non-EU human rights instruments to which the UK is and will remain bound.

\subsection{Main areas of contention: The compensation scheme}

\subsubsection{Outline}

The United Kingdom has decided not to introduce a compensation scheme with regards to the exceptions provided for in terms of implementing the Marrakesh Treaty. However, regulation 20 of the UK's Marrakesh Regulations states that the Secretary of State is to carry out a review of these Regulations, with the first such report being published before the 11th of October 2023. Whilst regulation 20 is not in itself problematic, it does become so when read in conjunction with both 
the Explanatory Memorandum, ${ }^{24}$ as well as the "Government Response to Marrakesh Consultation". ${ }^{25}$ In fact, the Explanatory Memorandum quotes from as well as provides a direct hyperlink to the IPO's 'Government Response to Marrakesh Consultation'. On pages 10-11 of this document, the government expressly states that the reason for including this review clause (which subsequently materialised as regulation 20 in the legislation) is to allow them to "assess the impacts of this decision [to not introduce a compensation scheme]" five years following implementation, "or sooner if evidence of economic harm and an associated need for compensation becomes apparent". As such, the UK government has left open the option of introducing a compensation clause at any time between the UK's Marrakesh Regulations coming into force, and the next five years. This is problematic for a multitude of reasons.

\subsubsection{Violating the EU Directive}

Firstly, it is argued that regulation 20 as read with the aforementioned documentation constitutes a violation of article 10 of the Marrakesh Directive. It must be noted that, whilst the EU has permitted member states to utilize the compensation scheme flexibility of the Marrakesh Treaty within their Marrakesh Directive per article 3(6), it permits member states to introduce compensation schemes prior to the deadline of 12 October 2018. Article 10 provides for a review on the decision to permit such compensation schemes within member states in 2023. The opposite is not true, in that it does not provide for member states who

24 Explanatory Memorandum to The Copyright and Related Rights (Marrakesh Treaty etc.) (Amendment) Regulations 2018 No. 995, available at http://www.legislation.gov.uk/uksi/2018/995/pdfs/uksiem 20180995 en.pdf (accessed 12 January 2019).

25 Intellectual Property Office, "Government Response to Marrakesh Consultation" (supra n. 5). 
choose not to implement a compensation scheme prior to the implementation date of 12 October 2018 to subsequently introduce such a scheme. To this end, the EU is tentative regarding the permanency of compensation schemes being permitted under article 3(6), as these compensation schemes will be subject to a review by the EU at the end of five years. Conversely, the UK is tentative regarding the commitment to maintain compensation-free access to works, with regulation 20 permitting the government to relinquish on this commitment at any time. In addition to being a violation of article 10, regulation 20 requires both disabled individuals as well as authorised entities to be on tenterhooks when exercising the Marrakesh exceptions in terms of the UK's Marrakesh Regulations, as at any time the compensation-free enjoyment could be revoked. This lack of legal certainty which undermines the spirit of the Marrakesh Treaty is particularly pertinent in light of the government failing to elaborate upon what it may consider to be sufficient "economic harm" to warrant the introduction of a compensation scheme in terms of regulation 20.

\subsubsection{Additional burdens on NGOs}

Secondly, a compensation scheme would introduce a burden/additional level of complexity upon authorised entities (such as NGOs) which may result in disabled individuals being unable to exercise their Marrakesh Treaty rights. ${ }^{26}$ Whilst beneficiary persons may not be made to pay compensation directly, the authorised entities will need to cover the costs (time, money, administration) of paying said compensation to the copyright owner in order for the disabled individual to access the work. If the authorised entity cannot cover these costs or operates at a loss when undertaking these enterprises, access by the intended

26 Helfer et al., supra n. 7, pp. 49-50. 
beneficiaries will effectively be denied. This is particularly damning in light of the socio-economic realities espoused below regarding disabled individuals in the UK being more likely to come from low-income backgrounds where access to works is all the more crucial.

\subsubsection{Disability discrimination}

Finally, compensation is usually paid as a means of making right a legal wrong that has cost the aggrieved party in some way. When one exercises a legally recognised exception in regards to another's property, this is considered to be outside - or excluded from - the ambit of the owner's monopoly right. As such, there is not considered to be any "loss" and therefore nothing to compensate. In recognising a claim for compensation from a copyright owner due to an authorised entity exercising a disabled individual's exception under UK legislation, there is the risk for discriminating between able bodied and disabled individuals in regards to copyright. For example, when a non-disabled individual chooses to exercise their fair dealing exception in relation to a copyright protected work, the law does not consider the copyright holder to have a claim for compensation - the copyright owner has not "lost" anything as his exclusive rights have not been infringed upon given the third party's use is a legally recognised exception to his right. Put differently, his copyright ends where the third party's exception begins. Why then if an authorised entity chooses to give effect to a disabled individual's Marrakesh exception by making accessible format copies - and in doing so acts as a conduit for the disabled individual - may it be said that the copyright owner is owed compensation from the authorised entity for "economic loss"? This differential treatment may arguably amount to ableism as it would effectively mean that disabled individuals are - albeit indirectly - having to pay a higher transactional cost for the same access to works that able-bodied individuals can enjoy for free. This is, 
it is posited, contrary to various commitments the UK has made in regards to diminishing discrimination against disabled individuals, some of which will be examined below. ${ }^{27}$

The UK is a signatory to the United Nations Convention on the Rights of Persons with Disabilities 2008. The Committee on the Rights of Persons with Disabilities is in charge of monitoring the implementation of the treaty. It does this by requiring Member States to submit reports on a regular basis outlining the legislative, policy and other steps taken to implement the treaty. ${ }^{28}$ According to article 9(1) of the convention, state parties have a duty:

[t]o enable persons with disabilities to live independently and participate fully in all aspects of life [and so] States Parties shall take appropriate measures to ensure to persons with disabilities access, on an equal basis with others $[\ldots]$ to information and communications, including information and communications technologies and systems.

This right to access to information and communications is more specifically addressed in article 21, which states that disabled people have the "freedom to seek, receive and impart information and ideas on an equal basis with others and through all forms of communication of their choice" (emphasis added). According to article 29 States Parties shall guarantee to persons with disabilities political rights and the opportunity to enjoy them "on an equal basis with others" (emphasis added), whilst article 30 protects their right to participate in a cultural life, recreation, leisure and sport and requires states to ensure disabled people enjoy equal access.

27 Ibid., pp. 15-19; Li and Selvadurai, supra n. 7; Abbe Brown, Charlotte Waelde, and Shawn SE Harmon, "Do you see what I see? Disability, technology, law and the experience of culture" (2012) 43(8) International Review of Intellectual Property and Competition Law 901-930.

282007 United Nations General Assembly Resolution 61/106 (2007), arts. 34-35. 
The United Nations Convention on the Rights of the Child 1989 was ratified by the UK in 1991 and deals specifically with the rights of disabled children to receive education. It is enforced through the Committee on the Rights of the Child. Member States must submit initial and periodic reports to the committee on the steps they have taken to give effect to the rights embodied in the convention, and the progress they have made in terms of the realisation of the rights embodied by the convention. The committee may request the involvement of specialised agencies where appropriate, and will address concerns and make recommendations to the State party. ${ }^{29}$ The purpose of the convention is to "protect children from discrimination, neglect and abuse", and does this by addressing their civil, political, economic, social and cultural rights. ${ }^{30}$ The particular ways in which this is done in the convention will be examined below.

According to article 23 of the Convention:

1. States Parties recognize that a mentally or physically disabled child should enjoy a full and decent life, in conditions which ensure dignity, promote selfreliance and facilitate the child's active participation in the community. [...] 3. Recognizing the special needs of a disabled child, assistance extended in accordance with paragraph 2 of the present article shall be provided free of charge, whenever possible, taking into account the financial resources of the parents or others caring for the child, and shall be designed to ensure that the disabled child has effective access to and receives education, training, health care services, rehabilitation services, preparation for employment and recreation opportunities in a manner conducive to the child's achieving the

291989 United Nations General Assembly Resolution 44/25 (1989), arts. 43-45.

30 United Nations Human Rights. "Monitoring children's rights" (2019), available at http://www.ohchr.org/EN/HRBodies/CRC/Pages/CRCIntro.aspx (accessed 16 April 2019). 
fullest possible social integration and individual development, including his or her cultural and spiritual development.

In this international instrument we see the importance the international community places on the right of disabled children to receive education as a way of enjoying a "full and decent life", and therefore recognising the correlation between the disabled child's right to receive an education and the disabled child's sense of self and dignity.

Next is the International Covenant on Economic Social and Cultural Rights 1976. Compliance is monitored by the Committee on Economic, Social and Cultural Rights. The UK ratified this Convention in 1976. All Member States are required to submit initial and periodical reports to the committee on the implementation of the Covenant and the committee will examine these reports, making recommendations and addressing its concerns. ${ }^{31}$ The aim of the covenant is to create the environment "whereby everyone may enjoy his economic, social and cultural rights, as well as his civil and political right" ${ }^{32}$ This it does in various ways. According to article 1, everyone has the right to self-determination, which means the right to "determine their political status and freely pursue their economic, social and cultural development". Article 6 deals with the right to employment, and states that parties to the ICESCR recognize the "right to work, which includes the right of everyone to the opportunity to gain his living by work which he freely chooses or accepts, and will take appropriate steps to safeguard this right". Coupled with the right to work must necessarily come the right to education, which is present in article 13, which states that everyone has the right to education, and that:

\footnotetext{
31 Ibid.

321966 General Assembly Resolution 2200A (XXI) (1966).
} 
(a) Primary education shall be compulsory and available free to all;

(b) Secondary education in its different forms, including technical and vocational secondary education, shall be made generally available and accessible to all by every appropriate means, and in particular by the progressive introduction of free education;

(c) Higher education shall be made equally accessible to all, on the basis of capacity, by every appropriate means, and in particular by the progressive introduction of free education

According to article 15, everyone has the right "to take part in cultural life" and to "enjoy the benefits of scientific progress and its applications". In this multilateral treaty we see the emphasis on education and its impact on other economic, social and cultural rights of the individual. For this reason it too provides strong support for the obligation on the UK government to amend its laws in order to provide equal access and achieve a fair, balanced copyright system.

Lastly, there is the UN Standard Rules on the Equalization of Opportunities for Persons with Disabilities. ${ }^{33}$ Although not a legally binding instrument, the Standard Rules represent a strong moral and political commitment of governments to take action to attain equalisation of opportunities for persons with disabilities. One of the most pertinent multilateral instruments regarding the subject of copyright accessibility is rule 5 of the United Nations Standard Rules on the Equalization of Opportunities for Persons with Disabilities, which deals specifically with state responsibilities regarding access for the disabled as a way of manifesting equal rights in all spheres. The specific duties placed on the state are to "introduce programmes of action to make the

331993 United Nations General Assembly Resolution 48/96 (1993). 
physical environment accessible" and more importantly for our purposes, to "undertake measures to provide access to information and communication". According to rule 5(b)(6),

\begin{abstract}
states should develop strategies to make information services and documentation accessible for different groups of persons with disabilities. Braille, tape services, large print and other appropriate technologies should be used to provide access to written information and documentation for persons with visual impairments.
\end{abstract}

From an EU perspective, there is the Charter of Fundamental Rights of the EU, which prohibits discrimination on the grounds of disability per article $21 .{ }^{34}$ Article 26 states that the EU Charter "recognises and respects the right of persons with disabilities to benefit from measures designed to ensure their independence, social and occupational integration and participation in the life of the community". The Court of Justice has held that a difference in treatment applied to a person according to whether or not he has a visual impairment is not, in principle, contrary to the prohibition on discrimination based on disability within the meaning of article 21(1) of the Charter, in so far as such a requirement actually fulfils an objective of public interest, is necessary and is not a disproportionate burden. ${ }^{35}$ Supporters of a compensation scheme would argue that it does fulfil an objective of public interest, namely protecting the economic rights of copyright holders. However, it is argued that making disabled people or the NGOs acting on their behalf pay compensation does no such thing. It must be stressed that the issue at play is not the cost of turning a traditional format work into an accessible format copy - it is the position of this paper that this cost

\footnotetext{
34 2012/C 326/02.

35 Case C-356/12 Wolfgang Glatzel v Freistaat Bayern, para. 50.
} 
is and indeed should be borne exclusively by the visually impaired individual or the authorised entity acting on their behalf. Nor is it the position of this paper that traditional format books should be made available to visually impaired individuals or authorised entities at a lesser price than they are made available to able-bodied individuals. The issue at play is with requiring disabled individuals or authorised entities to pay an additional compensation fee to the copyright holder in order to be allowed to turn a lawfully purchased book into an accessible format. As an able-bodied individual, I am able to purchase a traditional format book and - provided I have a voice recorder which is available readily and cheaply on sites such as Amazon and eBay - make a recording of myself reading it free of charge so as to listen to the audio version at will; as a visually impaired individual, this same action would inexplicably require the payment of a fee to the copyright holder. Put differently, the copyright-holder is able to obtain a double payment of royalties or some such payments from visually impaired individuals than he is from able-bodied individuals, and it is this doubling-up of profit that proponents of the compensation scheme would deem as worthy of legislative protection. It is argued that protecting the ability of copyright-holders to take financial advantage of the plight of visually impaired individuals is not an "objective of public interest", but a breach thereof.

It is vital to remember that - save for the EU Charter - these treaty-based duties will remain regardless of whether the UK leaves the EU. It is therefore the duty of the UK to ensure that there is no risk of discrimination against disabled individual with regards to accessing copyright-protected works. Implementing a compensation scheme, it is argued, risks breaching this duty and falling foul of the various human rights instruments examined above. 


\subsection{Main areas of contention: The commercial availability requirement}

\subsubsection{Outline}

Whilst the government is to be commended on removing the commercial availability requirement from its copyright legislation per the UK's Marrakesh Regulations, in light of the UK's longstanding and vehement opposition to the removal of the commercial availability requirement, ${ }^{36}$ the potential to reinstate the commercial availability requirement post-Brexit remains. In addition, the potentially broad scope of regulation 20 read with the related documentation may mean that there is the potential for the UK to reintroduce the commercial availability requirement if it is shown that the removal of such has resulted in 'economic harm'. For the reasons posited below, the commercial availability requirement arguably undermines the purpose and rationale for the Marrakesh Treaty.

On 25 October 2016, the Intellectual Property Office published a “Call for Views" on the European Commission's draft legislation to modernise the European copyright framework, including the Marrakesh Directive and corresponding Regulations. ${ }^{37}$ This call for views identified support for commercial availability restrictions among groups representing rights-holders, who argued that such provisions help to protect commercial markets, as indeed is the argument posited by Department for Business, Energy and Industrial Strategy who state that the rationale for having introduced the commercial

36 Court of Justice (Grand Chamber) Opinion 3/15 of 14 February 2017, paras. 40-46; Oppenheim, supra n. 7.

37 Intellectual Property Office, "Call for views: Modernising the European copyright framework", supra n. 3. 
availability requirement (as well as for wanting to maintain it in the implementation of the Marrakesh Treaty) is essentially that "if the UK is no longer able to limit the creation of accessible format copies to situations where they are not commercially available on reasonable terms, then authors, and commercial publishers, of accessible format copies may be negatively affected". ${ }^{38}$ Conversely, the commercial availability requirement may be seen as a necessary means in order to incentivise commercial publishers to originally publish accessible formats of their works. ${ }^{39}$ There was, expectedly, opposition among groups representing visually impaired people, who argued that these restrictions place unreasonable burdens on organisations which make accessible format copies, and that their removal would not affect commercial markets as these organisations have no incentive to make copies when they are already available commercially. ${ }^{40}$

\subsubsection{Uncertainty}

It is argued that there are various downfalls to introducing the commercial availability requirement. Firstly, there is no case law or authority to determine with certainty was "reasonable terms" mean in the UK context any more than there are in the international, Marrakesh Treaty context. Further, there is no definition for what "accessible" means, or how "accessible" a work must be

38 Baroness Neville-Rolfe, "Explanatory memorandum on European Union legislation" (3 October 2016), available at:

http://europeanmemoranda.cabinetoffice.gov.uk/files/2016/10/EM 12264-16 .pdf (accessed 23 January 2020).

39 Ibid.; Intellectual Property Office, "Consultation on UK's implementation of the Marrakesh Treaty", supra n. 4.

40 Intellectual Property Office, "Consultation on UK's implementation of the Marrakesh Treaty", supra n. 4. 
before it will be considered to have been commercially available in an accessible format. There is also the problem of compatibility issues. For example, where a work is only available in an accessible format on an iPad it would be unreasonable to expect a blind person to purchase an iPad simply so they can have access to a particular work. However, this may or may not be enough to deem the said work "commercially available" for the purposes of the Treaty, despite the clear practical absurdity. ${ }^{41}$

\subsubsection{Additional burdens on NGOs}

Secondly, such a clause puts the burden on institutions providing reading materials to the visually impaired to check whether the text is already available commercially and, if so, puts the additional burden on them to determine whether or not it is available under "reasonable terms". For institutions that are not made up of trained legal experts and which have limited resources (both human and financial), these demands are near impossible to satisfy, rendering the institutions practically paralysed to assist the visually impaired in any meaningful way for fear of facing a myriad of legal actions. This is an insurmountable obstacle for such organisations. This is especially evident when looking at developing nations, ${ }^{42}$ for example an organisation in South Africa wanting to send a book in an accessible format to another part of Africa, but it is equally as applicable to developed nations such as the UK. In such an instance the organisation would have no resources to perform the required checks, and so would effectively be unable to satisfy the said request due to purely pragmatic and economic reasons.

41 Helfer et al., supra n. 7, pp. 47-48; Kouletakis, supra n. 14; Brown et al., supra n. 27.

42 Olwan, supra n. 16. 


\subsubsection{Socio-economic realities of persons with disabilities}

Finally, according to the Equality and Human Rights Commission, in England, Wales and Scotland in 2013, disabled people were less likely to have accessed the internet compared with nondisabled people: England 65.1\% compared with 89.8\%; Wales 47.1\% compared with 85.7\%; Scotland 61.5\% compared with $88.2 \%{ }^{43}$ In $2015,27 \%$ of disabled adults had still never used the internet compared with $11 \%$ of non-disabled adults, which translates to over three million people. ${ }^{44}$ According to the Royal National Institute of Blind People, as of 2014 only seven per cent of books are available in formats that all blind and partially sighted people can read. ${ }^{45}$ According to the same Equality and Human Rights Commission report, UK data from 2014/15 shows the percentage of working-age adults in families where at least one member is disabled, and who were living in households with below $60 \%$ of contemporary median income after housing costs, was $30 \%$ compared with $18 \%$ for those living in families with no disabled members. ${ }^{46}$ These figures show 5.3 million individuals in households with below $60 \%$ of contemporary median income after housing costs and living in families where at least one member is disabled. ${ }^{47}$ The concept of poverty and technological barriers is not restricted to the developing world; it follows the disabled, wherever they might reside. If, as Baroness Neville-Rolfe and rightsholders claim, the justification for including a commercial availability requirement is to incentivise authors to publish in accessible format copies, then

43 Equality and Human Rights Commission, "Being Disabled in Britain" (2017), available at: https://www.equalityhumanrights.com/sites/default/files/being-disabled-in-britain 0.pdf (accessed 14 May 2018).

44 Ibid.

45 Royal National Institute of Blind People, "Could you help more children have access to books?" (2014), available at: https://www.rnib.org.uk/book-appeal (accessed 15 March 2018).

46 Equality and Human Rights Commission, supra n. 43.

47 Ibid. 
the lack of accessible format works in the free market is proof positive that the requirement does nothing to incentivise. Even if one were to ignore the publication statistics, one cannot ignore the correlation between disability and barriers to access: A significant portion of people who need accessible format copies are precisely the people who cannot afford to pay twice for them. So, even if costs were cut and e.g. audio-books were made cheaper, it would still be significantly out of the price-range of the poorer communities that make up a large part of the visually impaired in the first place. This means transaction costs for the visually impaired will be much higher than those for sighted readers which defeats the supposed aim of the Treaty.

\section{Conclusion}

The importance of the Marrakesh Treaty in realising the rights of access for those with disabilities is unquestionable. In analysing the UK's approach to the implementation of the Marrakesh Treaty, it has been argued that the UK's Marrakesh Regulations violates the EU Directive, potentially violates the human rights of its own citizens, leaves disabled individuals and authorised entities in a paralytic state of legal flux, and undermines the spirit and purport of the Marrakesh Treaty. It is the recommendation of this paper that revoking regulation 20 of the UK's Marrakesh Regulations would largely resolve these issues with relative ease. The concerns raised within this paper are both current and will remain ongoing regardless of whether Brexit materialises. As such, it is hoped that this paper will encourage greater scrutiny of the UK's Marrakesh Regulations by the academic community and stakeholders alike, with a call for legislative change as a matter of urgency. 